\title{
The Implications of a Harm Perspective on Terrorism, Road Safety, Tobacco, Alcohol, Illicit Drugs and Workplace Health and Safety
}

This policy paper addresses issues around crime impacts and crime prevention from a harm perspective. The development of the paper was prompted by the 2014/15 escalation of counter-terror measures in Australia. The paper begins with a brief review of crime measurement issues and of a harm perspective in guiding crime prevention policies. It then engages in an analysis of impact measures around four diverse crime and harm types in Australia: terrorism, road crashes, drugs (tobacco, alcohol and illicit drugs), and workplace health and safety violations. The case studies highlight the success of Australia's counterterror program in preventing attacks on Australian soil and contrasts this with major ongoing harms associated with the alleged under-regulation of the other crime types. The evidence indicates that much more attention needs to be given to these latter areas to achieve large improvements in people's well-being, without necessarily reducing efforts to combat terrorism.

\section{Background}

The measurement of diverse types of crime and victimisation is important because accurate data are needed to test theories of offending and victimisation, to assess the effectiveness of crime prevention policies, to prioritise responses and to justify the use of limited public resources. The two main types of crime data are 'administrative' data (e.g. police, courts, hospitals, etc.) and crime experience surveys (Manning, 2009). Administrative data collected and reported by governments provide a key performance measure for objectives of security and safety, and direct demands on justice and associated agencies. However, these data have a number of well-known limitations in only reflecting crimes reported to police or detected by police (or other law enforcement agencies). Crime experience surveys therefore provide an important corrective. These tend to be focused on victimisation, including fear of crime, but they can include self-reporting of criminal conduct, including, for example, drug use. Although surveys are often considered as separate to administrative data, many surveys are managed and reported by governments. Arguably they could also therefore be considered 'administrative' or 'official' data.

In Australia, there are three main repositories of official data on crime in different formats. The Australian Bureau of Statistics provides data on recorded crime and findings from an annual crime experience survey (http://www.abs.gov.au/ausstats). The Australian Institute of Criminology repackages the ABS data and a number of other sources in the annual Australian Crime: Facts and Figures series (http://www.aic.gov.au/publications). The Productivity Commission also repackages ABS and other data in its annual reports on government services (http://www.pc.gov.au/research). Collectively, these data indicate that for conventional crime categories - such as assault, burglary, motor vehicle theft, and theft more than three million individuals have been victimised in Australia annually in recent years out of a population of approximately 23 million. While property crimes have been trending down since the turn of the century, violent crime rates have been fairly stable on the whole.

There have been a number of valuable innovations in crime measurement in recent decades, including crime mapping and surveys of business and government (e.g., http://crimetool.bocsar.nsw.gov.au, www.aic.gov.au). The latter are particularly valuable in showing the extent of fraud and attempted fraud, marking an ongoing widening of government interest in diverse crime-related problems. Two associated developments of particular relevance to the present study include financial costs of crime estimates and the overlapping focus on the harm component of crime. The Australian Institute of Criminology 
published the first Australian costs of crime study in 1992. The third study was published in 2014, covering the year 2011. It estimated direct costs (stolen property, lost earnings, hospitalisation, etc.) at \$23 billion, and indirect costs (private security, insurance, criminal justice, etc.) at $\$ 24$ billion, with a total figure of $\$ 47.6$ billion (Smith, et al., 2014).

The collection and reporting of crime data, and innovations in this area, are predicated on crime as harm and the need to reduce crime-related harms. The notion of harm is, of course, traditionally the most significant factor in defining criminal offences and assigning penalties according to seriousness. In a democracy, harm and threated harms are also meant to inform the allocation of police resources on a triage basis. In both cases, however, the imputation of harm has been a very inexact science and some criminologists are calling for a more developed science of harm and a greater focus on preventing crimes with more harmful effects as well as addressing harms such as fear of crime (Paoli \& Greenfield, 2013; Ratcliffe, 2015). Fear of crime can, of course, include fear of a terrorist attack. The Cambridge 'crime harm index' represents one recent effort to advance the practical application of the concept of harm, including greater consideration of the destructive impacts of the actions of a small numbers of serious repeat offenders (Sherman, 2011). Crime-related harms also include inappropriate interventions by criminal justice personnel. Examples include discrimination and excessive force by police - contributing to reduced public confidence in government authority - as well as excessively punitive responses to minor offences (Sherman, 2011).

Harm can be estimated in quantitative terms in a variety of ways. Obvious factors include lethality, injury, disability and psychological damage. Some of these data can be collected and reported numerically on an annual basis, and some can be assigned a financial loss or cost figure. Overall, this is obviously a complicated analytic process with considerable ambiguity and likely controversy. For example, Frey and Luechinger (2003) point out, in relation to data on terrorist attacks, that a simple category of 'injury' can be quite complicated: 'The problem arises that being seriously injured, with permanent disabilities persisting for the rest of one's life (e.g., if victims lose their eyesight) differs markedly from being only lightly injured. There can be no strict rule as to what to count and what to disregard' (p. 4). However, these kinds of problems are not fatal to the mission of putting metrics on harms. For example, in the field of workplace health and safety, degrees of incapacity are calculated, as are periods of absence from injuries (e.g., Safe Australia, 2012).

Surprisingly perhaps, despite the proliferation of crime data and concerns about terrorism, there appears to be no standardised annual public reports on terrorism threats and incidents for Australia. This might be because of the very low rate of terrorism cases over the longer term, and because publicising low incidence rates might adversely affect institutional interests in perceptions of a high terrorist threat (cf., Benson, Rasmussen \& Sollars, 1995). Internationally, a major source, which includes Australia, is the annual Annex of Statistical Information, Country Reports on Terrorism produced in the United States by the National Consortium for the Study of Terrorism and Responses to Terrorism (START), attached to the US Department of Homeland Security Science and Technology Center of Excellence at the University of Maryland. There are a number of issues associated with the START data around definitions of terrorism and the reliability of sources. Nonetheless, START is widely recognised as a comprehensive and consistent source of international comparative data over time across a number of dimensions including incidents, injuries and fatalities; although it does not distinguish between domestic and transnational terrorism (see Enders \& Olson, 2011). Information for Australia is also available on an ad hoc basis from government press releases and periodic reviews about counter-terrorism strategies and expenditures.

In contrast to terrorism data, Australian government agencies routinely publish large volumes of data in the three other key crime-related areas of harm discussed in this paper: road crashes, drugs, and workplace health and safety. The Bureau of Infrastructure, Transport 
and Regional Economics publishes detailed data on road crashes and associated harms and financial losses, some of which are included in Productivity Commission reports. The Australian Institute of Health and Welfare and National Drug and Alcohol Research Centre publish data on drug-related harms, and the Commonwealth Department of Health and Ageing has produced two detailed reports on costs of tobacco, alcohol and illicit drug abuse. Data on workplace injuries and illnesses are available in annual and periodic reports from Safe Work Australia.

\section{Four Case Studies}

The following sub-sections summarise key Australian data on four crime-related problems: terrorism, traffic crashes, drugs (tobacco, alcohol and illicit drugs), and workplace health and safety. Terrorism was selected in response to the 2014/15 escalation of federal government investments in counter-terror strategies and this case study is the most detailed. The other three case studies were selected because of the ongoing large scale harms involved - with the partial exception of illicit drugs - and the enormous potential for very large improvements through better government intervention: whether this is called crime prevention, regulation, policing or something else.

Given that terrorism provides the trigger for this study, and given the salience of the 9/11 attacks and the inauguration of a post-9/11 security environment, the data are focused on the post 9-11 period. In the main, this means that the data cover the period 2002/03 to 2012/13, with some data up to 2014. This provides a rough 'decade' for reviewing accumulated harms and trends.

\section{Case Study 1: Terrorism}

Available data indicate that Australia's counter-terrorism strategies appears to have been extraordinarily successful post-9/11. Using the START material (above), in the main period under review, from 2002/03 to 2012/13, no one was killed or injured in a terrorist attack on Australian soil (START, 2014). It is possible that the attack on the Lindt Café in Sydney in December 2014, involving two deceased victims, by a gunman asserting a Muslim agenda, will be counted as a terrorist event in Australia - although considerable controversy has already occurred around this definitional issue (Cater, 2014). However, it must be emphasised that, according to official sources, Australia has a remarkable record of no injuries nor fatalities from terrorism in the post-9/11 decade to 2013 (see also DPMC, 2015).

The situation in Australia contrasts markedly with that in many other countries.

According to the START reports, in 2013 there were 9,707 terrorist attacks around the world, a total of 17,891 persons were killed, 32,577 were injured and 2,990 kidnapped or taken hostage (START, 2014, p. 3; see also Institute for Economics and Peace, 2015). Attacks declined from 10,283 in 2011, but fatalities increased from 12,533 and the number of injured persons increased from 25,903. Attacks have been concentrated in Iraq, with 2,495 attacks in 2013, and 6,378 killed and 14,956 wounded (p. 4). Pakistan and Afghanistan had the next highest concentrations.

Terrorism has also been associated with a large range of other harms. For example, Abadie and Gardeazabal's (2008) study confirmed findings from earlier studies which demonstrated a large negative association between terrorism and a countries' net stock of foreign direct investment (FDI). Specifically, they found that a one standard deviation change in terrorism risk (similar to moving from a risk at the level of Italy to the level of the USA) induces a fall in net GDP of about 5\%. FDI is an important source of national savings, and a reduction in FDI will ultimately negatively affect investment and long-term economic growth 
(Frey, Luechinger, \& Stutzer, 2007). Eckstein and Tsiddon (2004) found a negative association between terrorism and domestic consumption, while Blomberg and Hess (2006) found that a single terrorist incident is associated with a 5.1 percentage point decline in bilateral trade.

Australia's anti-terror strategy includes preventing entry to persons suspected of terrorist intentions, and also identifying and shutting down home-grown plots. The most prominent example of the latter is Operation Pendennis in 2005, which resulted in arrests of conspirators in Melbourne and Sydney, leading to 21 convictions related to terrorism planning (Jopson, 2012). The 2015 report of the Review of the Commonwealth's Counter Terrorism Arrangements lists five foiled plots post-9/11 up to 2014 - including Pendennis, a planned attack on the Holsworthy Army barracks, and a recent plan for a random attack on a member of the public (DPMC, 2015, p. 15). A total of 35 prosecutions and 26 convictions were reported for 'terrorism-related offences' (p. 14).

The total financial cost of security-oriented counter-terror strategies is unknowable because resources and strategies are targeted at terrorism along with many other activities, such as smuggling of contraband, and embedded across numerous government agencies, including Defence, the Australian Secret Intelligence Organisation, the Australian Secret Intelligence Service, Office of National Assessments, Customs and Border Protection, the Australian Federal Police, and state and territory agencies. However, a number of ad hoc reports have set out some specific expenditures. A Counter-Terrorism White Paper, released in 2010, announced a $\$ 200$ million commitment to aviation and border security over four years, including $\$ 69$ million allocated to fingerprint and facial recognition technologies (DPMC, 2010). Overall, the Review of the Commonwealth's Counter Terrorism Arrangements, published in January 2015, reported that expenditures 'dedicated' to counter-terrorism - on very approximate estimates - rose from $\$ 100$ million in 2001/02 to $\$ 800$ million in 2007/08, declining to $\$ 500$ million in 2013/14 but expected to rise to $\$ 600$ million in 2015/16 (DPMC, 2015, p. 9). The total for the 11 year post-9/11 period was approximately $\$ 6.3$ billion. Presumably these figures included, or overlapped with, security expenditure for the 2014 G20 Summit in Brisbane, put at $\$ 97.5$ million for policing and \$8 million for the defence forces (Pickering, 2014).

In 2014, a new wave of counter-terror measures was triggered by the sudden success of Islamic State in launching a ground war and capturing large swathes of Syria and Iraq. Islamic State recruited fighters from Western democracies and it encouraged 'lone wolf' attacks in various countries including Australia. In response, the Australian government raised the terror alert level to High and introduced additional counter-terror measures. The government had staked its credentials on reducing Australia's mountain of debt. However, the Prime Minister announced an additional \$632 million 'to boost the counter-terrorism capacity of the Australian Federal Police, ASIO, ASIS, Customs and Border Protection and other agencies' (Abbott, 2014, p. 1).

Following the Lindt café siege and the completion of the Review of the Commonwealth's Counter Terrorism Arrangements, in February 2015 the Prime Minister made a national security address in which he announced a further raft of counter-terror initiatives and expenditures. These were also prompted by a number of other 'lone wolf' attacks in other democracies. According to the Prime Minister, 'On all metrics, the threat to Australia is worsening' (Abbott, 2015, p. 1). He also reported that 'The number of serious investigations also continues to rise. ASIO is currently investigating several thousand leads and persons of concern. Roughly 400 of these are high priority cases, more than double a year ago' (p. 1). The 2015 review noted that approximately \$7 million had been allocated per annum for future community-based programs to counter radicalisation, but that this needed a substantial boost (DPMC, 2015, p. 32). However, in March 2015, The Australian revealed that available 
evidence indicated that expenditures to-date to counter home-grown terrorism showed no evidence of success and probable evidence of large-scale waste (Parnell, 2015).

\section{Case study 2: Road crashes}

When it comes to deaths and injuries, a very different picture is apparent for road crashes. Between 1975 and 2013, the number of deaths per 100,000 people fell from 8.8 in 2002 to 5.2 in 2013. This was at a time when the Australian population increased by 66 per cent and vehicle registrations increased by 174 per cent (Bureau of Infrastructure, Transport \& Regional Economics, 2014a). At the same time, in the 11 year post-9/11 timeframe - from 2002-03 to 2012-13 - a staggering 16,348 people died on Australian roads (Steering Committee for the Review of Government Service Provision, 2014; also Bureau of Infrastructure, Transport \& Regional Economics, 2014b). During the same period, 432,695 people were injured to the point where they needed to be hospitalised, and the number of individuals seriously injured increased. Between 2002 and 2011, there was a 22\% increase in the number of hospitalised injuries as the result of traffic crashes (Bureau of Infrastructure, Transport \& Regional Economics, 2014a).

The cost of road crashes in both human and economic terms is extremely high and includes losses to workplaces and homes, repair costs, insurance administration, medical and other health related costs, travel delays, and costs involved in operating another vehicle as well as legal costs. The costs vary per type of crash with the Bureau of Infrastructure, Transport and Regional Economics (2009) estimating the cost at \$2.67 million per fatal crash, $\$ 266,000$ per hospitalised injury crash, $\$ 14,700$ per non-hospitalised injury crash, and a property damage only crash at \$9,950. The total cost of crashes in Australian in 2006 was estimated at $\$ 17.85$ billion (Risbey, Cregan, \& De Silva, 2010). A rough estimate of road crash costs from 2002-13 can be calculated by multiplying the 2006 figure by 11 . This suggests the cost of road crashes for this period was $\$ 196.35$ billion. Road crash costs are not static over time with the cost of road crashes falling from 1996 to 2006. Aspects that decreased included travel delays, vehicle repair costs, legal costs, and disability-related costs, as well as costs associated with a lower quality of life. Aspects that increased between 1996 and 2006 were workplace and household losses, insurance administration and medical-related costs (Bureau of Infrastructure, Transport and Regional Economics, 2009). Overall, it is likely that the estimates of road crash costs are conservative, particularly given the probable under-reporting of road crashes to government authorities (Connelly \& Supangan, 2006).

\section{Case study 3: Drugs}

Another example of significant harms concerns two regulated drugs - alcohol and tobacco. Unfortunately, reliable data in a time series format are not readily available in Australia for these types of drug use. The most recent data estimating the number of deaths and financial costs (e.g., hospitalisation costs, lost productivity, etc.) are for 2004-05 (Collins \& Lapsley, 2008). For 2004-05, deaths attributed to alcohol were put at 3,494 and total costs at $\$ 15.3$ billion (2008, pp. 53 \& 65). For tobacco, the figures were 15,050 and $\$ 31.5$ billion. Taking the 2004-05 figures and multiplying by 11 would be a way of generating a very rough overall estimate for the post-9/11 period. The result is an estimated 38,434 deaths from alcohol over 11 years, and $\$ 168.5$ billion in costs. For tobacco, the figures are 165,550 deaths and $\$ 346.3$ billion in costs.

Surprisingly perhaps, harms from illicit drugs are much lower. The National Drug Strategy Household Survey findings, from 2001 to 2010, show remarkably stable rates of both long-term and recent illicit drug use, with a solid proportion of the population - 
averaging $15.0 \%$ of adults - using illicit drugs in a 12 month period (Australian Institute of Health and Welfare, 2011, pp. 8, 86). However, most of this is cannabis use. Average usage rates are much lower for ecstasy (3.2\%), amphetamines (2.7\%), cocaine (1.5\%) and heroin $(0.2 \%)$. Fatalities are also relatively small in number. Collins and Lapsley put deaths from illicit drugs in Australia in 2004/05 at 872 (2008, p. 52). This was a much lower number than deaths, above, from alcohol - 3,494 - and tobacco - 15,050. According to Australian Institute of Health and Welfare data, non-intentional deaths from cocaine and methamphetamines, as an 'underlying cause of death', are generally very small. From 2001 to 2009 the average number of deaths attributed to cocaine was 4.7, and 17.7 for methamphetamines (Roxburgh \& Burns, 2013, p. 3). Numbers do not appear to be available for heroin. Collins and Lapsley put the financial costs of illicit drugs at $\$ 8.2$ billion in 2004/05 (2008, p. 63), averaging out to $\$ 90.1$ billion over 11 years. The number of deaths from illicit drugs was put at 872 (p. 56). Only one death was attributed to cannabis. Multiplying by 11 we get a total very rough estimate of 9,592 - compared to 38,434 deaths from alcohol 165,550 from tobacco.

\section{Case study 4: Workplace harms}

Finally, workplace deaths and injuries provide another area of harm related to breaches of safety regulations, but also breaches of criminal law in some cases. Data collected by Safe Work Australia for the 11 years 2003 to 2013 identified 2,806 'worker fatalities’ (2014, p. 7). These figures do not include 'work-related disease fatalities' resulting from exposure to hazards, such as chemicals. Exposure incidents have been related to 'between 2,300 and 7,000 deaths annually' (Safe Work Australia, 2012, p. 24). Work-related injuries and diseases resulted in 2,610 fatalities in one year alone - 2008-09 - in one of the more recent reports available (Safe Work Australia, 2012, p. 24). In addition, in the same year, 3,700 persons suffered 'full incapacity', 82,100 suffered partial incapacity, and 185,600 experienced a 'long absence' from work (5 or more days). The overall costs to employers, employees and the community for the same year were put at approximately $\$ 60.6$ billion (p. 27).

Over 11 years post 9/11, the figures sum to approximately 28,600 fatalities from harmful exposure, 903,100 cases of partial incapacity, 40,700 cases of full incapacity and $\$ 666.6$ billion in costs. Safe Work Australia (2012, p. 23), estimated the following spread of financial costs:

- employers bear 5 per cent of the total cost - this includes loss of productivity from absent workers, recruitment and retraining costs and fines and penalties from breaches of work health and safety regulations;

- injured workers bear 74 per cent of the costs - costs include loss of current and future income and non-compensated medical expenses; and

- the community bears 21 per cent of the total cost - this includes social welfare payments, medical and health scheme costs and loss of potential output and revenue.

\section{Discussion and Policy Implications}

The data presented above demonstrate profound inconsistencies in the harms associated with different regulated or prohibited activities. In the 11 years post-9/11, the harms associated with traffic crashes, tobacco and alcohol, and adverse workplace incidents have been enormous. The numbers belie the highly personal physical and emotional pain and loss. Despite declines in most areas, incidents continue at very high levels, with immense financial costs for individuals, communities and governments (see also Manning, Smith \& Mazerolle, 2013). The contrasts are most marked in relation to terrorism, where no deaths or injuries 
were recorded on the Australian mainland. They also contrast with relatively low levels of fatalities and losses from illicit drugs.

These contrasts become even more marked when compared to legal, financial and strategic investments in law enforcement. The post-9/11 period has seen massive investments worldwide in counter-terror capacity. As noted above, in Australia, this has involved at least $\$ 6.3$ billion in 'dedicated' expenditures. There have also been recurring enlargements of legal prohibitions and penalties for activities related to terrorism planning or support. Illicit drug law enforcement can similarly be considered 'heavy', with long prison terms for possession and trafficking, and a focus on the 'sharp end' of law enforcement through raids, seizures and arrests (Australian Crime Commission, 2014). In contrast, government control over driving, tobacco, alcohol and workplace safety can all be described as 'light', despite significantly increased enforcement in recent decades (Ransley \& Prenzler, 2015). Supply and consumption of alcohol and tobacco are also subject to 'light' regulation, with ready access by adults. Estimated harms and associated levels of law enforcement, detailed above, are summarised in table 1, highlighting these deep contradictions.

Table 1: Estimated harms post 9/11, 2002/03 - 2012/13

\begin{tabular}{|l|r|r|r|r|}
\hline & \multicolumn{1}{|l|}{ Fatalities } & Injuries & Financial costs & $\begin{array}{l}\text { Law } \\
\text { enforcement }\end{array}$ \\
\hline Terrorism & 0 & 0 & $\$ 6.3$ billion & Heavy \\
\hline Traffic crashes & 16,348 & $432,695^{*}$ & $\$ 196.3$ billion & Light \\
\hline Drugs & & & & Light \\
\hline Alcohol & 38,434 & - & $\$ 168.5$ billion & Light \\
\hline Tobacco & 165,550 & - & $\$ 346.3$ billion & Heavy \\
\hline Illicit drugs & 9,592 & - & $\$ 90.1$ billion & Light \\
\hline Workplace ‘accidents’ & 28,600 & $903,800^{* *}$ & $\$ 666.6$ billion & \\
\hline
\end{tabular}

* Hospitalised. ** Partial \& full incapacity.

These data support the case for a clearer focus on harm in the development of crime prevention policies. Resources need to be targeted where they are most likely to produce the greatest benefits in reducing human suffering. From this perspective, it would seem that the preoccupation - sometimes the hysteria - around terrorism in Australia is severely misplaced or, at best, way out of balance in relation to what would appear as appropriate responses to threats from other sources. However, this perspective need not entail a case for reducing counter-terror budgets or counter-terror strategies. Overall, it would seem appropriate not only to maintain successful strategies, but to address heightened terror threats with enhanced security, including at critical infrastructure sites and with advanced intelligence-based strategies of pre-emption. As indicated above, the harms associated with terrorism are not limited to the direct effects of successful attacks. The insidious threat of a terror attack reduces public confidence in tourist and recreational activities, and reduces investor confidence. Perceptions are important. In a sense, the routine carnage on the roads represents a known and familiar threat that appears to have little adverse impact on usage, whereas the unlikely but potentially spectacular nature of a terror attack evokes much greater caution.

The threat of terrorism, as opposed the incidence, is a particularly important consideration because there has been recurring evidence of significant weaknesses in Australian airport security procedures post-9/11. The absence of terror attacks may have been, at least in part, the result of an absence of attempts (Prenzler, Lowden, \& Sarre, 2010; Wheeler, 2005) - a situation that could change at any time. Australia could also play a more 
decisive role in international efforts to reduce terrorism. The rise of Islamic State and the failure to intervene early in the Syrian civil war is a tragic case in point. Where proposed innovations involve concerns about privacy and civil liberties - in areas such as meta-data retention legislation for example - there needs to be a consensus oriented decision-making process. Rather than weakening counter-terror strategies, Australia needs to maintain its status as essentially terror-free.

What needs to done, however, is to apply the same standard to the other harms analysed in this paper: road trauma, adverse effects of drugs, and workplace injuries. It might argued that preventive interventions in these areas entail excessive financial costs or restrictions on commerce and personal liberties. For example, political inhibitions around greater regulation of traffic often assume a simplistic trade-off between mobility and safety (Bates, Watson, \& King, 2010). However, the astonishing levels of trauma and financial losses in this area indicate wide scope for reduced downstream costs, and also for improved freedoms through travelling, working and recreating in an environment of safety. Furthermore, the literature on crime prevention shows clearly that early intervention can produce costs-to-savings ratios as high as 1-to-7; and there are sufficient successful crime prevention case studies on the record to show that standard crime prevention processes of diagnosis, intervention, monitoring and modification will work and be cost-effective when applied systematically to diverse crimerelated problems (Manning \& Wong, 2014).

As indicated above, there have been enormous improvements in road safety in many countries, including Australia, since the 1970s. Successful strategies have included safer road design; safer vehicle design; and enlarged surveillance, sanctioning and incapacitation (Bates, Watson \& Soole, 2012). Compulsory seat belts, random breath testing and speed detection have been crucial innovations. But despite large improvements, road trauma remains at entirely unacceptable levels. A much more concerted effort needs to be put into tightening regulatory controls on driving. Speed remains a critical factor. Speed limits need to be reduced, especially where vehicles driving in opposite directions are not separated by barriers, and there needs to be much closer surveillance and more painful sanctioning of violations. There is a strong case for increases in drug and alcohol testing programs, but with the addition of an educative component (Bates, 2014; Mazerolle, et al., 2012).

The majority of drivers are highly dependent on driving and responsive to threats to their legal right to drive. There are also small groups of serious and repeat offenders who need to be subjected to much higher levels of control through imprisonment, licence revocation, vehicle impounds and ignition locks (Bates, et al., 2012). The successes of mandated vehicle security need to be matched with mandated safety features, such as roll cages and electronic stabilisation programs. This is particularly important as road safety has tended to blame the driver for crashes rather than looking for situational countermeasures that can be used to reduce incidents. Historically, there has been a need for governments to regulate the inclusion of various safety features as the vehicle manufacturing industry has opposed routine installation in vehicles (Hakkert \& Gitelman, 2014). For instance, the airbag was invented in 1951 and was installed in some vehicles within the United States in 1973. However, it was not routinely installed in vehicles until the 1990s.

When it comes to drugs, the claim is often heard that 'prohibition doesn't work'. This is partly the reasoning behind the current system of relatively liberal access to alcohol and tobacco. As noted above, very rough estimates from the Collins and Lapsley study (2008) for the post-9/11 period would attribute about 38,434 deaths to alcohol and \$168.5 billion in costs; with 165,550 deaths from tobacco $\$ 346.3$ billion in costs. This was compared with prohibited drugs, where the same rough calculations show much lower rates of harm: 9,592 deaths and $\$ 90.1$ billion in costs. This is a heavily policed area. Illicit drug offences account for around $12 \%$ of the most serious offences leading to imprisonment, and is the highest rated 
offence, at 18\%, for female imprisonment (Australian Bureau of Statistics, 2013). There are on average about 70,000 arrests in Australia for illicit drug offences each year (Australian Institute of Criminology, 2014, p. 38). However, about 60,000 of these are for cannabis. As indicated in the data section of this study, very few deaths are attributed directly to cannabis in official government reports - although it is known to be a factor in traffic crashes and in mental illness (Asbridge, Hayden \& Cartwright, 2012; Renard, et al., 2014). The Australian data therefore support the established scientific view that illicit drugs are generally much less harmful than legal drugs such as alcohol and tobacco (Nutt, et al., 2010).

What do the data on drugs mean? In a nutshell, they suggests that prohibition and policing of illicit drugs could reasonably be maintained alongside enlargement of more positive primary prevention and relapse prevention strategies that have shown beneficial outcomes - such as therapies, methadone, employment, and employment skill building (Ministerial Council on Drug Strategy, 2011). At the same time, one implication of 'success' with illicit drugs is that a more restrictive approach to alcohol and tobacco could produce very large reductions in fatalities and costs. In fact, the harms associated with tobacco are so extreme that they would justify putting tobacco in the same category as cocaine and amphetamines - engaging in total prohibition. No doubt, this would stimulate a small illicit market, but the efforts required to suppress the market would most likely be justified if harms were reduced to the same levels as those currently pertaining to illicit drugs. Alcohol, on the other hand, is so enmeshed in Australian social life and commerce that prohibition would be unacceptable and might provoke the pervasive illicit trade and corruption that occurred in prohibition America. Nonetheless, there are promising Australian studies showing reductions in alcohol-related violence from improvements in responsible serving practices and late-night lockouts from licensed premises (Graham \& Homel, 2008). There is also evidence of reduced consumption associated with taxing and pricing by volume of alcohol (Marsden Jacob Associates, 2012).). However, the issue of what works in reducing alcohol-related harms appears to be an area where much more scientific research is needed.

Finally, there is also large scope for reducing adverse workplace incidents. In the context of modern workplace health and safety legislation, harms occurring at work derive primarily from the significant under-policing of standards (Ransley \& Prenzler, 2015). The failure to protect workers needs to be recognised as a crime, with much greater application of an enforcement pyramid involving close inspection, warnings, orders, fines and prosecutions as necessary. In While you were sleeping: Success stories in injury and violence prevention, Hemenway (2009) documents some of the extraordinary achievements in workplace safety in the United States (p. 44):

Between 1933 and 1997 the unintentional work-related fatality rate fell by 90 percent, from 37 per 100,000 to 4 per 100,000; in absolute numbers, during a century in which the workforce more than tripled from 39 million to 130 million, the annual number of workplace deaths feel from 14,500 to 5,100.

This change is largely attributed to a shift from the 'victim blaming' attitude to legislated employer responsibility and associated changes to the work processes and workplace environments. Hemenway (2009) included seven case studies of large and sustained reductions in workplace fatalities, injuries and illnesses through strategies such as outlawing hazardous products, applying taxes that made manufacture of hazardous products non-viable, mandated safety technology, and sacking of workers refusing to comply with safety standards. In policing, as one example of a workplace, there is strong evidence that fatalities and injuries for both officers and members of the public, have been reduced, and can be further reduced, through data-driven analyses of adverse incidents; profiling of at-risk 
officers; and changes to procedures, technologies and training (Prenzler, Porter \& Alpert, 2013).

\section{Conclusion}

What should be done about the contradictions and hypocrisies in policies around terrorism, road crashes, drugs and workplace safety in Australia? This paper has argued that successful counter-terror strategies should be maintained and enhanced as new threats emerge, but with more stakeholder input around possible threats to civil liberties. Strategies that have contributed to the successful prevention of harms from illicit drugs should also be maintained but augmented, hopefully eventually supplanted, with a wider range of 'harm reduction' options beyond a simple policy of disrupt, arrest, incarcerate and repeat. When it comes to the enormous harms directly attributed to tobacco use, the success of illicit drug prohibition suggest this would be a viable means of minimise harms from tobacco. Prohibition of alcohol is unlikely to find acceptance, but much more can be done to reduce harmful drinking. Road safety and workplace safety also appear as areas where very large gains can be made through a much smarter, more concentrated approach, to regulation, including increased law enforcement when necessary. The well-being and longevity of many millions of Australians would be greatly enhanced through a more scientific approach to the policing of diverse crime and safety problems.

\section{References}

Abadie, A., \& Gardeazabal, J. (2008). Terrorism and the world economy. European Economic Review, 52(1), 1-27.

Abbott, T. (2014, September 12) National terrorism public alert level raised to high. Retrieved from www.pm.gov.au/media/2014-09-12/national-terrorism-public-alert-level-raised-high

Abbott, T. (2015). Review of Australia's Counter-Terrorism Machinery for a Safer Australia. www.pm.gov.au/media/2015-02-23/review-australias-counter-terrorism-machinery-safer-australia0 .

Asbridge, M., Hayden, J., \& Cartwright, J. (2012). Acute cannabis consumption and motor vehicle collision risk: systematic review of observational studies and meta-analysis research. The BMJ, 344, e536 (1-9).

Australian Bureau of Statistics (2013). Prisoners in Australia. http://www.abs.gov.au/ausstats/abs@.nsf/Lookup/by\%20Subject/4517.0 2013 Main\% 20Features Most\%20Serious\%20Offence\%20or\%20Charge 16.

Australian Crime Commission (2014). 2012-13 illicit drug data report. Canberra: Author.

Australian Institute of Criminology (2013). Australian crime: Facts and figures 2012. Canberra: Author.

Australian Institute of Health and Welfare (2011). 2010 national drug strategy household survey report. Canberra.

Bates, L. (2014). Procedural justice and road policing: Is it important? Paper presented at the Road Safety Research, Policing and Education Conference, Melbourne.

Bates, L., Soole, D., \& Watson, B. (2012). In T. Prenzler (Ed.), Policing and security in practice: Challenges and achievements (pp. 90-109). Houndmills: Palgrave-Macmillan.

Bates, L., Watson, B., \& King, M. (2010). Mobility and safety are conflicting goals for transport policy makers when making decisions about graduated driver licensing. International Journal of Health Promotion and Education, 48(2), 46-51.

Benson, B. L., Rasmussen, D. W., \& Sollars, D. L. (1995). Police bureaucracies, their incentives, and the war on drugs. Public Choice, 83(1-2), 21-45. 
Blomberg, S. B., \& Hess, G. D. (2006). How much does violence tax trade? The Review of Economics and Statistics, 88(4), 599-612.

Bureau of Infrastructure, Transport and Regional Economics. (2009). Road crash costs in Australia 2006. Canberra: Author.

Bureau of Infrastructure Transport and Regional Economics. (2014a). Impact of road trauma and measures to improve outcomes. Canberra: Author.

Bureau of Infrastructure Transport and Regional Economics. (2014b). Road deaths Australia: 2013 Statistical Summary. Canberra: Author.

Cater, N. (2014, 23 December). ABC struggles with I-word. The Australian, p. 12.

Collins, D. \& Lapsley, H. (2008) The Costs of tobacco, alcohol and illicit drug abuse to Australian society. Canberra: Commonwealth Department of Health and Ageing.

Connelly, L., \& Supangan, R. (2006). The economic costs of road traffic crashes: Australia, states and territories. Accident Analysis \& Prevention, 38, 1087-1093. doi: 10.1016/j.aap.2006.04.015

DPMC (2010) Counter-Terrorism white paper: Securing Australia: Protecting our community. Canberra: Department of the Prime Minister and Cabinet.

DPMC (2015) Review of Australia's counter-terrorism machinery. Canberra: Department of the Prime Minister and Cabinet.

Eckstein, Z., \& Tsiddon, D. (2004). Macroeconomic consequences of terror: theory and the case of Israel. Journal of Monetary Economics, 51(5), 971-1002.

Enders, W., \& Olson, E. (2011). Measuring the economic costs of terrorism: Oxford handbook of the economics of peace and conflict.

Frey, B. S., \& Luechinger, S. (2003). Measuring terrorism IEW Working paper 171. Zurich: Institute of Empirical Research in Economics, University of Z"urich.

Frey, B. S., Luechinger, S., \& Stutzer, A. (2007). Calculating tragedy: Assessing the costs of terrorism. Journal of Economic Surveys, 21(1), 1-24.

Graham, K., \& Homel, R. (2008). Raising the bar: Preventing aggression in an around bars, clubs and pubs. Cullompton: Willan Publishing.

Hakkert, A., \& Gitelman, V. (2014). Thinking about the history of road safety research: Past achievements and future challenges. Transportation Research Part F: Traffic Psychology and Behaviour, 25, 137-149.

Hemenway, D. (2009) While you were sleeping: Success stories in injury and violence prevention. Berkeley: University of California Press.

Institute for Economics and Peace. (2015). Global terrorism index. Retrieved 16 February, 2015, from http://economicsandpeace.org/research/iep-indices-data/global-terrorismindex

Jopson, D. (2012, February 4) Homegrown jihad. The Sydney Morning Herald, p. 1.

Manning, M. (2009). Establishing an evidence base: Program evaluation. In A. Stewart, T. Allard \& S. Dennison (Eds.), Evidence based policy and practice in juvenile justice. Brisbane: Federation Press.

Manning, M., Smith, C., \& Mazerolle, P. (2013). The societal costs of alcohol misuse in Australia. Trends \& Issues in Crime and Criminal Justice, 454, 1-6.

Manning, M., \& Wong, G. (2014). Financial costs and benefits of crime prevention. In T. Prenzler (Ed.), Professional practice in crime prevention and security management (pp. 41-58). Samford Valley, QLD: Australian Academic Press.

Marsden Jacob Associates (2012). Bingeing, collateral damage and the benefits and costs of taxing alcohol rationally: Report prepared for the Foundation for Alcohol Research and Education. Perth: Author. 
Mazerolle, L., Bennett, S., Antrobus, E., \& Eggins, E. (2012). Procedural Justice, Routine Encounters and Citizen Perceptions of Police: Main Findings from the Queensland Community Engagement Trial (QCET). Journal of Experimental Criminology, 8, 343367.

Ministerial Council on Drug Strategy (2011) National Drug Strategy 2010-2015. Canberra: Author.

Nutt, D. J., King, L. A., \& Phillips, L. D. (2010). Drug harms in the UK: A Multicriteria decision analysis. The Lancet, 376(9752), 1558-1565.

Paoli, L. \& Greenfield, V.A. (2013) ,Harm: A Neglected concept in criminology, a necessary benchmark for crime-control policy‘. European Journal of Crime, Criminal Law and Criminal Justice, 21, 359-377.

Parnell, S. (2015, 10 March) \$5m lost reaching out to Islamists. The Australian, p. 2.

Pickering, H. (2014, November 12). G20 Brisbane: \$100 million to protect world leaders. http://www.brisbanetimes.com.au/queensland/brisbane-g20/g20-brisbane-100-millionto-protect-world-leaders-20141112-11l7e0.html.

Prenzler, T., Lowden, C., \& Sarre, R. (2010). Aviation security issues in Australia post-9/11. Journal of Policing, Intelligence and Counter-Terrorism, 5(2), 9-22.

Prenzler, T., Porter, L., \& Alpert, G. (2013). Reducing police use of force: Case studies and prospects. Aggression and Violent Behavior: A Review Journal, 18(2), 343-356.

Ransley, J., \& Prenzler, T. (2015). White collar crime. In H. Hayes \& T. Prenzler (Eds.), An Introduction to crime and criminology (pp. 134-152). 4th Edition. Sydney: Pearson.

Ratcliffe, J. (2015). Towards an index for harm-focused policing. Policing: A Journal of Policy and Practice, 9(2), 164-182.

Renard, J., Krebs, M., Le Pen, G., \& Jay, T. (2014). Long-term consequences of adolescent cannabinoid exposure in adult psychopathology. Frontiers in Neuroscience, 8, 361. doi: 10.3389/fnins.2014.00361.

Risbey, R., Cregan, M, \& de Silva, H. (2010) Social costs of road crashes. Australasian Transport Research forum 2010, 29 September to 1 October Canberra.

Risbey, T., Cregan, M., \& De Silva, H. (2010, 29 September - 1 October). Social cost of road crashes. Paper presented at the Australasian Transport Research Forum, Canberra.

Roxburgh, A., \& Burns, L. (2013). Cocaine and methamphetamine related drug-induced deaths in Australia, 2009. Sydney: National Drug and Alcohol Research Centre.

Safe Work Australia (2012) The Cost of work-related injury and illness for Australian employers, workers and the community: 2008-09. Canberra: Safe Work Australia

Safe Work Australia (2014). Work-related traumatic injury fatalities, Australia, 2013. Canberra: Safe Work Australia.

Sherman, L. W. (2011). Al Capone, the sword of Damocles, and the police-corrections budget ratio. Criminology \& Public Policy, 10(1). 195-206.

Smith, R.G., Jorna, P., Sweeney, J., \& Fuller, G. (2014). Counting the costs of crime in Australia: A 2011 estimate. Canberra: Australian Institute of Criminology.

START (2014). Annex of statistical information, Country reports on terrorism 2013. Baltimore: National Consortium for the Study of Terrorism and Responses to Terrorism, US Department of Homeland Security Science and Technology Center of Excellence, University of Maryland.

Steering Committee for the Review of Government Service Provision (2014). Report on Government Services, Volume C: Justice, Police Services, Chapter 6, Attachment Tables. Canberra: Author.

Wheeler, J. (2005). An Independent review of airport security and policing for the Government of Australia. Canberra: Department of Transport and Regional Services. 